\title{
Financing Agriculture in Nigeria through Agricultural Extension Services of Agricultural Development Programmes (ADPS): The Case of Edo State, Nigeria
}

\author{
Henry Inegbedion* \\ Landmark University, Nigeria
}

Submission: July 03, 2018, Published: September 05, 2018

"Corresponding author: Henry Inegbedion, Landmark University, KM 4, Ipetu Road, Omu Aran \r \nKwara State, Nigeria; Tel: 08032962970;

Email: inegbedion.henry@lmu.edu.ng

\begin{abstract}
The ADPs were designed in response to a fall in agricultural productivity and hence a concern to sustain domestic food supplies. The study examined financing agriculture in Nigeria through agricultural extension services of ADPs. It sought to ascertain the extent to which agricultural extension services of the ADPs have impacted the financing of agriculture in six communities in three selected local government areas in Edo South senatorial district, Nigeria using a sample of 120 respondents. Stratified random sampling was used to select the respondents. Interview schedule served as the research instrument. The research data were analyzed using one sample t-test ANOVA and multiple regression techniques, which served as the inferential statistics. The research findings showed that the extension services of ADP have impacted significantly on crop and farm development in the selected communities but not on employment creation and the development of infrastructural facilities. The study also revealed that there was significant difference between the implementation of the projects in the selected communities, as revealed by the post hock test. On the basis of the research findings, the need for a complete redesign of the project and proper monitoring of its implementation to ensure that it achieves its stated goals was suggested, among others.
\end{abstract}

Keywords: ADPs; Nigerian economy; Agricultural sector; Fertilizers; Rural communities

Abbreviations: ADPs: Agricultural Development Projects; ICT: Information and Communication Technology; SPSS: Statistical Package for Social Sciences

\section{Introduction}

Prior to independence, agriculture was the mainstay of the Nigerian economy. Even at threshold of independence the scenario did not show any change, as agriculture contributed well over ninety percent to the nation' foreign exchange earnings. However, with the discovery and subsequent exploitation and exportation of crude oil in commercial quantities, the contribution of agriculture to the nation' s foreign exchange and GDP began to dwindle as attention shifted from agriculture to Oil [1]. The domination of the other sectors of the economy by the oil sector made the Nigerian economy a monoculture with the attendant implications. This led to the disengagement of many able-bodied men from productive activities in search for oil money, thus precipitating an unprecedented rural-urban drift in the 1970s. The neglect of the agricultural sector and the subsequent rural-urban drift created a visible dent in Nigeria's food supply and thus signaled the need to embark on massive importation of food stuffs in the early 1980s.

Government's response to the glaring distortion was to embark on a series of interventionist programmes referred to as the Agricultural Development Projects (ADPs). The ADPs were initiated in the mid-1970s as Nigeria's oil production and revenues were rapidly expanding and stimulating rapid urban growth [2]. The ADPs were designed to increase crop production through a coordinated approach to rural development. The main elements were improved technology (and the means to get it to farmers), increased supply of farming inputs (especially fertilizers), and extensive infrastructure improvements (especially rural roads and water supplies) [3]. At the initial stage, three pilot enclave projects were undertaken in the northern part of the country. By the late 1970s, the initial results were considered sufficiently encouraging to justify expansion [2]. Accordingly, a series of similar projects, some covering whole states, were prepared and implementation began in the early 1980s and lasted through the decade. Bendel ADP, which later became Edo ADP in 1992, was among this group. Each of these groups included four basic components, farm and crop development (expanded research, extension, and input supply), infrastructure development (feeder road construction and maintenance, water supplies, markets and storage facilities), institutional support, establishment of project entities separate from the state agriculture departments, and technical assistance, 
largely to manage the new institutions. Owing to the perceived importance of ADP to agricultural development in Nigeria several studies have been conducted to evaluate its performance since inception, some of the recent studies include Adamu \& Mohammed [4], Enwelu, Enwereuzor, Asadu, Wallej \& Nguoke [5], Naswem \& Ejembi [6], Umeh OJ, Ekumankama 00, Nwachukwu I \& Ekwe KC [7], Omonijo, Toluwase, Oludayo \& Uche [8], Nchuchuwe \& Adejuwon [9], Ammani, Auta \& Aliyu [3], Ugwu [10], as well as Olujenyo [11], among others.

\section{Objectives of the Study}

The main objective of the study was to determine the impact of agricultural extension services of Edo state ADP on agricultural financing in Edo state using six selected communities in three local government areas in Edo south senatorial district, by focusing on the activities of Edo ADP Extension Division. The specific objectives of the study are to determine: The extent to which the extension services of Edo ADP have impacted farm and crop development in the selected communities under study; the extent to which the extension services of Edo ADP have impacted infrastructural development in the communities under its coverage, and the extent to which the extension services of Edo ADP have contributed to the reduction of unemployment through the attraction of able-bodied men and women to agriculture.

\section{Literature Review}

Human history is replete with a list of past civilizations which flourished but eventually declined partly as a result of inadequate management of their respective environments. In order to forestall a repeat of history, there is need to devote adequate attention to the good management and conservation of the environment so that increased food, fibers, and other resources can be produced at minimum cost as well as ensure that the risk to the survival of future generations is minimized [12]. Agricultural development, a subset of economic development, implies a substantial increase in the level of production and productivity over a reasonable length of time and the subsequent improved wellbeing of farmers as reflected in their higher per capita income. Rural development, which is part of the central focus of AP, relates, not only to a sustained increase in the level of production and productivity of all rural dwellers, including farmers and a substantial improvement in their wellbeing manifested by increasing per capita income and standard of living; but also leads to a sustained physical, social and economic improvement of rural communities [9]. Rural development can thus be seen as a veritable tool for fighting poverty and achieving economic prosperity at the grass root level. The concept of rural development embraced by most countries connotes a process through which rural poverty is alleviated by sustained increases in the productivity and incomes of lowincome workers and households [13].

\section{Concept of ADP}

The ADPs were designed in response to a fall in agricultural productivity and hence a concern to sustain domestic food supplies, as labour had moved out from agriculture into more remunerative activities that were benefiting from the oil boom [2]. Conversely, domestic recycling of oil income provided the opportunity for the government, with bank support, to develop the ADPs. The projects provided agricultural investments and services, rural roads, and village water supplies. The government's adoption of the ADPs put the smallholder sector at the centre of the agricultural development strategy and marked a clear shift away from capital intensive investment projects for selected areas of high agricultural potential.

The first ADPs were enclave projects each covering a specific region within a state. Their early results impressed both the federal and state governments and there was pressure on the government to replicate the approach across all the states of the federation. By 1989, all the states of the federation, nineteen states then, had ADPs; which sought to increase food production and farm incomes. In all, it was assumed that productivity increases would result from the use of improved technology, especially planting material and fertilizer. The agricultural components of the projects were designed around systems for developing technology and transferring same to farmers, distributing modern inputs, and land development, including small-scale irrigation of FADAMA areas in the north, and land clearing. Investments in infrastructure included expanded feeder road network, construction of farm service centers for input distribution, as well as facilities for ADP staff and operations. All the projects, except that in Ilorin, supported improvements in rural water supplies.

\section{EDO State ADP}

ADP was established in Benin City in 1986 with focus on all the local government areas in the old Bendel state. With the creation of Edo state in 1991, the focus (coverage areas) of the scheme became restricted to all the local government areas in Edo state. Like what obtains in all the Northern states of the federation, the scheme is a tripartite arrangement between the federal, states, and local governments. That notwithstanding, at the moment, the state government is solely responsible for the payment of staff salaries. The areas of intervention of Edo ADP include infrastructural development, such as construction and maintenance of earth roads; provision of water through the sinking of Boreholes in the communities; building of markets; and provision of storage facilities; as well as farm and crop development (rural agriculture) through the provision of fertilizers, pesticides and farm implements to rural farmers at subsidized rates as well as the provision of consultancy services and public enlightenment of farmers.

The FADAMA programme of the ADP, which began in the north has also taken off in the south and is currently undertaken by Edo ADP. FADAMA involves interventionist programmes, using relevant methodologies in areas were water is close to the surface of the earth. The frequency of intervention is contingent upon necessity as well as availability of funds, but also subject to political consideration at times. The major constraints currently being faced by Edo ADP include: Inadequate manpower; and the preference of the state ministry of agriculture over ADP 
by the administration of Edo state. The situation is was alleged to be threatening the capacity of the Edo ADP to embark on its traditional interventionist programmes since such functions are now being contracted to the Ministry of Agriculture in mid-2000.

\section{Empirical Review}

Naswem \& Ejembi [6], investigated "reviving agricultural extension for effective transition from subsistence to commercial agriculture". They sought to identify factors that led to the erosion of the extension system and point the path to an effective revitalization of the system as part of the new agricultural transformation agenda policy. They discussed the theoretical roots of the ADP that drives the Nigerian extension system, and the contribution that extension can make to the success of the agenda. They also highlighted the weaknesses of past extension efforts. The need for the younger generation to be deliberately involved in agriculture was suggested, among others.

Ammani, Auta \& Aliyu [3], investigated the "challenges to the sustainability of the ADP system in Nigeria" with a view to analysing the problems constraining the sustainability, and by implication, the effective performance of the ADP system in Nigeria. The focal problem was inadequate funding. They developed and transposed a problem tree, thus transforming the root causes and consequences identified into root solutions. Consequently, the need to focus on improving funding for the ADPs through deduction of state and federal governments counter-part funds for the ADPs from source was suggested among others.

Olujenyo [11], investigated the "impact of ADP on the quality of social existence of rural dwellers in developing economies in Ondo state (Nigeria)". The purpose of the study was to examine the impact of the ADP on the farmers in the rural areas of Ondo state, Nigeria, West Africa; by ascertaining its impact on the farming operations of its target farmers, the farmer-related factors and the organizational factors that are associated with the impact of the ADP. Survey design was employed, and structured questionnaire was used to elicit information from 288 respondents consisting of 144 contact farmers and 144 non-contact farmers using random and systematic sampling respectively. Correlation analysis was used to test the hypotheses formulated. The results revealed that there was a significant difference in mean yields of the hectarage of land cultivated by the farmers and mean score of articles of convenience possessed by the farmers before after the inception of the ADP in all the four crops examined.

Nchuchuwe \& Adejuwon [9], investigated "the Challenges of agriculture and rural development in Nigeria". They observe that African agriculture remains largely traditional and concentrated in the hands of smallholders and pastoralists, and the neglect of agriculture has precipitated negative net migration. They further discuss the problems and challenges posed by this and government responses to the rural infrastructural needs of the people. The need for an adequate level of strategically targeted investment in agriculture, upgrade of rural infrastructure, boosting of productivity and increase competitiveness of the farm output were, suggested among others.

Ugwu [10], examined "contributions of ADPs to rural livelihood and food security in Nigeria" The genesis and historical development of the ADP system were presented. They observed that the critical mandate/objective of the ADPs was to boost agricultural production as well as contribute to rural livelihood and food security. The achievements and impact of the ADPs were identified to be in the area of revitalized extension service, local capacity building, rural infrastructural development, input distribution, technology development, transfer and adoption, as well as improved rural livelihood and food security. Significant ADP achievements in the above focus areas have guaranteed programme continuity for the past two decades in Nigeria. The major challenges were undue political interference by some state governments, cash flow instability due to irregular payment of counterpart funding by some state governments, rapid staff turnover in most ADPs and adverse effects of some macro-economic policies of government, among others. The need for government to give increased political support was suggested, among others.

Adamu \& Mohammed [4], investigated "the effect of ADP on the rural farmers in Adamawa state, Nigeria". Data were collected on annual crop output, annual income, farm size, and use of improved technology, access to credit among farmers, farmers' training and rural infrastructure as well as structured questionnaire and personal interviews while t test was used to analyze the data. The results indicate that Adamawa ADP had positive and significant impact on rural farmers' productivity, income, access to credit, standard of living as measured by assets ownership. However, there was no significant impact on the rural infrastructure, adoption of improved technologies and farm sizes. Consequently, the need to enhance the provision of rural infrastructure and the needed technologies; as was as fund the project adequately were recommended, among others.

Omonijo, Toluwase, Oludayo \& Uche [8], examined "impacts of ADP on rural dwellers in Nigeria using the people of Isan Ekiti, Oye Local Government Area of Ekiti state as case". The survey method was employed, and questionnaire served as the instrument. They retrieved and analysed 73 questionnaires using descriptive and inferential statistics. Multiple linear regression analysis served as the inferential test. Results reveal that there was a significant relationship between ADP (through increased provision of pesticides, improved seeds to farmers, establishment of new infrastructure as well as provision of fertilizers) and increased food production in the locality. However, accessibility of credit by farmers had no significant effect on increased Agricultural productivity. The need for government to increase its effort in the area of agricultural credit financing was suggested.

Umeh, Ekumankama, Nwachukwu \& Ekwe [7], compared the performance of the ADP of Abia and Enugu states, Nigeria. They evaluated the performance of ADPs of Abia and Enugu states, Nigeria; with particular focus on extension services delivery in the 
study areas. Multi-stage sampling technique was used to select 200 respondents made up of 40 extension staff and 60 farmers from each state. Primary and secondary data were employed. Paired t-test was used in hypothesis testing. Results showed that 3 (number of extension agents, farm visits and monthly review meetings) out of the 11 extension performance indices measured in the two States' ADPs, showed significant difference at 5\% level in the performance of Abia and Enugu states ADPs. Consequently, the need for government to make haste to employ better trained extension staff to enhance service delivery in Enugu State was suggested.

Enwelu, Enwereuzor, Asadu, Walleji \& Nguoke [5], investigated the "access and Use of information communication technologies in Anambra State ADP". Multi stage sampling was used to select 69 respondents from the zones, blocks and circles and questionnaire was used to elicit the desired data. The data were analysed using descriptive statistics, exploratory factor analysis and simple linear regression. It was observed that mobile phone was highly accessible to extension workers as well as in ADP office and very often used. Poor ICT skills, inadequate support by organization and government and high cost of maintenance of ICT tools were found to militate against extension workers' access and use of ICTs. Number of ICTs owned was found to have significant influence on level of ICT utilization among extension workers.

\section{Methodology}

The study adopted the cross-sectional survey design since it sought to ascertain respondents' perception of "agricultural extension services ADP in Edo State" using a research instrument. The population of the study consisted of small scale farmers in Edo south senatorial district. Six communities, two each from three local government areas of Ikpoba-Okha, Egor, and Oredo local government areas were the focus of the study. The communities were Iyekogba, Ogba, Etete, Evboriaria, Egor and Ugbiyokno.

It was desired to be ninety-five percent (95\%) confident that the perception of the sampled respondents will not differ by more than nine percent from the perception of the true population of the study.

Thus, $n=\frac{Z_{a} / 2^{2}}{4 D^{2}}$

Where;

$\mathrm{Z}=$ standard score corresponding to the level of significance ( 0.05 in this case) and $\mathrm{D}=$ maximum allowable difference between the true population proportion and the sampled respondents, which is also 0.09 in this case Agbadudu [14].

Consequently, ${ }^{n}=\frac{1.96^{2}}{4 x 0.09^{2}}=118.6$. This value was approximated to 120 . Using a total sample size of 120 , twenty (20) respondents were sampled in each community. The interior parts of the communities around the village heads were focusessssd on, to ensure access to the rural farmers. Thus, the communities were stratified according to the nearest fifty compounds to the resident of the village head. Subsequently, simple random sampling was used to select the desired number of respondents from each community. Thus, the sampling technique used was stratified random. Subsequently, an interview schedule was used to elicit the necessary information from the sampled respondents. The choice of the interview schedule as the research instrument was informed by its flexibility which allows items to be adapted to the respondents' level of education. The interview schedule had two parts - the Bio-data, which featured items on the respondents' demographic characteristics and the core-subject matter, which featured items that addressed the research problem. The question-response format of the research questions was the Likert type five-point scale with options ranging from a region of strong agreement (strongly Agree), through a neutral zone (Not Sure), to a region of strong disagreement (Strongly Disagree). Research data were analyzed, using descriptive statistics such as mean, standard deviation, mean difference and standard error mean; as well as inferential statistics - t-test for Equality of means, ANOVA and regression analysis. Data analysis were implemented using the Statistical Package for Social Sciences (SPSS) 23.0 [15-20].

\section{Results}

\section{Introduction}

Out of the 120 sampled respondents, information was initially elicited from 111 of them while the remaining 9 could not appear for the survey. A supplementary sample was done to replace the 9 that could not volunteer information. The results of the data analysis are presented below.

\section{Test if hypotheses}

Six hypotheses were tested. The results of the tests are presented below

\section{Agricultural extension services of EDO, ADP vs. crop development}

Table 1: Agricultural Extension Services of ADP vs. Crop Development.

\begin{tabular}{|c|c|c|c|}
\hline \multicolumn{4}{|c|}{ N Mean Standard Deviation Standard Error Mean } \\
\hline \multicolumn{4}{|c|}{ Responses 103.180 .880 .08} \\
\hline Test Value $=3$ & Sig. & Mean & \multirow{3}{*}{$\begin{array}{l}95 \% \text { confidence } \\
\text { interval of the } \\
\text { Difference }\end{array}$} \\
\hline \multicolumn{3}{|c|}{ t. df 2 Tailed Difference Lower Upper } & \\
\hline \multicolumn{3}{|c|}{ Responses 2.280 .120 .0240 .1830 .0260 .34} & \\
\hline
\end{tabular}

A comparison of Agricultural Extension Services with crop development in the communities revealed that the mean score associated with respondent's perception of the extent to which Edo ADP has influenced crop development projects in their communities was 3.18 with a standard deviation of 0.88 and a standard error mean of 0.08 . Against a test value of 3 , this resulted in a mean difference of 0.18 . A t-test for equality of means revealed that this difference was significant at the five per cent level since the significant (2-tailed) probability of 0.024 is less than 0.05 , the assumed level of significance. Consequently, at the ninetyfive percent (95\%) confidence level, the agricultural extension services of Edo ADP have significantly affected farm development in the communities (Table 1). 
Agricultural extension services of EDO, ADP vs. farm development

A comparison of Agricultural Extension Services of Edo ADP with Farm development in the communities revealed that the mean score associated with respondent's perception of the extent to which Edo ADP has influenced farm development projects in their communities was 3.16 with a standard deviation of 0.74 and a standard error mean of 0.35 . Against a test value of 3 , this resulted in a mean difference of 0.16 . A t-test for equality of means revealed that this difference was significant at the five per cent level since the significant (2-tailed) probability of 0.031 is less than 0.05 , the assumed level of significance. Consequently, at the ninety-five percent (95\%) confidence level, it is safe to conclude that the agricultural extension services of Edo ADP have significantly affected farm development in the communities (Table 2).

Table 2: Agricultural Extension Services vs. Farm development.

\begin{tabular}{|c|c|c|c|}
\hline \multicolumn{4}{|c|}{ N Mean Standard Deviation Standard Error Mean } \\
\hline \multicolumn{4}{|c|}{ Responses 1203.160 .740 .35} \\
\hline Test Value $=3$ & Sig. & Mean & \multirow{3}{*}{$\begin{array}{l}95 \% \text { confidence } \\
\text { interval of the } \\
\text { Difference }\end{array}$} \\
\hline \multicolumn{3}{|c|}{ t. df 2 Tailed Difference Lower Upper } & \\
\hline \multicolumn{3}{|c|}{ Responses 2.280 .120 .0310 .1590 .0260 .035} & \\
\hline
\end{tabular}

Agricultural extension services of EDO, ADP vs. development of infrastructural facilities

Table 3: Agricultural Extension Services vs. Development of Infrastructural Facilities.

\begin{tabular}{|c|c|c|c|}
\hline \multicolumn{4}{|c|}{ N Mean Standard Deviation Standard Error Mean } \\
\hline \multicolumn{4}{|c|}{ Responses 1203.150 .860 .078} \\
\hline Test Value $=3$ & Sig. & Mean & \multirow{3}{*}{$\begin{array}{l}95 \% \text { confidence } \\
\text { interval of the } \\
\text { Difference }\end{array}$} \\
\hline \multicolumn{3}{|c|}{ t. df 2 Tailed Difference Lower Upper } & \\
\hline \multicolumn{3}{|c|}{ Responses 1.820 .120 .0570 .150 .0050 .304} & \\
\hline
\end{tabular}

A comparison of Agricultural Extension Services of Edo ADP with development of infrastructural facilities in the communities revealed that the mean score associated with respondents perception of the extent to which Edo ADP has influenced the development of infrastructural facilities in their communities was 3.15 with a standard deviation of 0.86 and a standard error mean of 0.078 . Against a test value of 3 , this resulted in a mean difference of 0.15 . A t-test for equality of means revealed that this mean difference was not significant at the five per cent level since the significant (2-tailed) probability of 0.057 is not less than 0.05 the assumed level of significance. Consequently, at the ninety-five percent (95\%) confidence level, the agricultural extension services of Edo ADP have not significantly influenced the development of infrastructural facilities in the communities (Table 3).

\section{Agricultural extension services of EDO, ADP vs. reduction in the level of unemployment}

A comparison of Agricultural Extension Services with reduction in unemployment revealed that the mean score associated with respondents' perception of the extent to which Edo ADP has influenced the reduction of unemployment in their communities was 3.147 with a standard deviation of 0.853 and a standard error mean of 0.074 . Against a test value of 3 , this resulted in a mean difference of 0.147 . A t-test for equality of means revealed that this difference was not significant at the five per cent level since the significant (2-tailed) probability of 0.064 is not less than 0.05 the assumed level of significance. Consequently, at the ninety-five percent (95\%) confidence level, the agricultural extension services of Edo ADP have not significantly influenced the reduction in the level of unemployment in the communities (Table 4).

Table 4: Agricultural Extension Services vs. reduction in Unemployment.

\begin{tabular}{|c|c|c|c|}
\hline \multicolumn{4}{|c|}{ N Mean Standard Deviation Standard Error Mean } \\
\hline \multicolumn{4}{|c|}{ Responses 1203.1470 .8530 .074} \\
\hline Test Value $=3$ & Sig. & Mean & \multirow{3}{*}{$\begin{array}{l}95 \% \text { confidence } \\
\text { interval of the } \\
\text { Difference }\end{array}$} \\
\hline \multicolumn{3}{|c|}{ t. df 2 Tailed Difference Lower Upper } & \\
\hline \multicolumn{3}{|c|}{ Responses 1.680 .120 .0640 .1470 .020 .301} & \\
\hline
\end{tabular}

\section{Respondents' perception vs. location}

A comparison of respondents' perception with their location revealed that there was a significant difference between respondents' perception and location since the computed $\mathrm{F}$ and associated significant probabilities were 5.82 and $0.003(\mathrm{p}<0.01)$ respectively, thus indicating that at $99 \%$ confidence level, the effect of ADP is different in the locations (Table 5). A post hock test revealed that the impact of ADP in Egor local government was not significantly different from Ikpoba Okha but significantly different from Oredo (Tables 5 \& 5A).

Table 5: Agricultural Extension Services Location of Respondents.

Source of variation Sum of Squares df. Mean Square F Sig.

Between Groups (LGAs) 12.42226 .2115 .8240 .003

Within Groups (LGAs) 380.7333571 .066

Total 393.156359

Table 5A: Post Hock Tests (Homogeneous Subsets).

\begin{tabular}{|c|c|}
\hline \multicolumn{2}{|c|}{ Subset for $\boldsymbol{\alpha}=\mathbf{0 . 0 5}$} \\
\hline Location of Respondents N 12 \\
\hline Oredo Local Government Area 120 & 3.15 \\
\hline Egor Local Government Area 120 3.517 & 3.567 \\
\hline Ikpoba Okha Local Government Area 120 &
\end{tabular}

Extension services of EDO, ADP vs. crop/farm and infrastructural development as well as reduction in unemployment

Table 6 presents the regression analysis with extension services of ADP serving as the dependent variable while crop/ farm development, infrastructural development and reduction in unemployment are the independent variables. The intention of this model is to establish the nature of the relationship between extension services of ADP and the explanatory variables. Here, the 
argument is based on the fact that if $\mathrm{Y}$ is directly proportional to $\mathrm{X}$, then $\mathrm{X}$ is also directly proportional to $\mathrm{Y}$. the results show that the adjusted $\mathrm{R}$ square is 0.42 , thus indicating that the independent variables explain $42 \%$ of the variation in the dependent variable. Furthermore, only crop/farm development was significantly related to extension services of ADP. Infrastructural development and reduction in unemployment were not significant. Interestingly the relationship between extension services of ADP and reduction in Unemployment was negative thus indicating that increased extension services will translate to a reduction in unemployment (Table 6-8).

Table 6: Model Summary.

Model R Square Adjusted E square Std Error of Estimate DWStatistic

0.710 .510 .420 .50581 .76

Predictors: (crop/farm production, infrastructural development, unemployment reduction).

Dependent variable: Extension services of ADP.

Table 7: ANOVA.

\begin{tabular}{|c|c|}
\hline Model Sum of Squares & df. Mean Square F. \\
\hline Regression 286.29 3128.764 4.36 0.019 & \\
\hline Residual 3479.072 11629.992 & \\
\hline Total 3765.362 119 & \\
\hline
\end{tabular}

Dependent variable: Extension services of ADP.

Predictors: (crop/farm production, infrastructural development, unemployment reduction).

Table 8: Coefficients.

\begin{tabular}{|c|}
\hline Unstandardized Standardized Coefficients \\
\hline Model B Std. Error Beta t Sig \\
\hline Constant 2.56 0.62 2.12 0.034 \\
\hline Crop/Farm Development 0.1710 .0420 .363 .560 .012 \\
\hline Infrastructural Development 0.0870 .2110 .0981 .180 .073 \\
\hline Reduction in Unemployment $-0.0760 .26-0.103-1.340 .054$ \\
\hline
\end{tabular}

Dependent variable: Extension services of ADP.

\section{Discussion of Findings}

The findings show that agricultural extension services of ADP have had significant impact on crop and farm development. However, the results do not indicate significant impact on reduction in unemployment and development of infrastructural facilities in the sampled communities. The results are consistent with the findings of Olujenyo [11], Ugwu [10], Omonijo, Toluwase, Oludayo \& Uche [8] and Umeh, Ekumankama, Nwachukwu \& Ekwe [7]. Also, the non-significance of agricultural extension services of ADP on infrastructural facilities is consistent with the findings of Adamu \& Mohammed [4]. Furthermore, the results show that the impact of ADP on the local governments is not the same. In other words, the impact of the ADP is more in some locations than others. This is consistent with Enwelu, Enwereuzor, Asadu, Walleji \& Nguoke [5]. Lastly, the negative relationship between extension services of ADP and unemployment reduction indicates that with proper implementation of ADP, unemployment may be reduced. This is a point of departure from previous studies that examined impact of ADP on employment creation without ascertaining the nature of the relationship between them the two variables.

\section{Conclusion}

Agricultural Extension services of ADP have so far impacted crop and farm development significantly but have not has significant impact on infrastructural development and reduction in rural unemployment. To this end, the extension services have been impactful but have not fully exerted the desired impact on the communities in Edo state. The reason may not be unconnected with the manner of implementation. The pattern of intervention in some of the areas was significantly different others. Furthermore, it appears that the commitment of government to the projects has suffered some setbacks and the pump and pageantry that heralded its inception has subsided significantly.

This study has made significant contribution to agricultural research literature by updating previous studies on ADP in Nigeria. Furthermore, with the inverse (negative) relationship between the extension services of ADP and reduction in unemployment, it is evident that ADP made some impact, but the impact was not significant. The implication is that with proper commitment to the extension services of ADP the level of unemployment in the country will be significantly reduced. To some extent, this is a point of departure from most previous studies because they made no attempt to demonstrate the possibility of the extension services of ADP contributing to employment creation and hence reduction in unemployment.

The study was not without limitations, which could constrain the generalizability of the results of this study. First, the inability of the researcher to obtain a completely random sample, owing to logistic concerns in the rural areas was a limitation because randomness is a prerequisite for representativeness. Nevertheless, efforts were made to minimize this constraint. Secondly, the unwillingness of some sampled respondents to volunteer the desired information was a big challenge and could have further distorted the desired randomness in sample selection. The unwillingness was tackled by consistent persuasion which eventually saw only nine (9) remaining adamant in the final analysis. These nine were eventually replaced through supplementary sampling.

\section{Recommendations/Suggestions for Further Studies}

In view of the findings, the following recommendations are suggested: Firstly, concerned authorities should show adequate commitment and willingness to the success of the ADP by restrategizing and reengineering the extension services with a view to making it more encompassing in order to yield the desired impact; secondly, concerted efforts should be made to use the $\mathrm{ADP}$ as a means of rejuvenating agricultural sector to boost the self-reliance and self-sufficiency in food production agenda of the federal government of Nigeria as well as the diversification of the 
nation's resource base; lastly, there is the need to also redesign the scheme to address the shortcomings, which are currently threatening to truncate the programme. Future studies should

\section{Appendix: Questionnaire}

\section{Section A}

Instruction: Mark X in the box as appropriate [X] (Table 9).

Table 9: Instruction: Please indicate the extent to which you agree with the following items by writing 1, 2, 3, 4 or 5 in the response box.

\begin{tabular}{|c|c|c|}
\hline S/N & Construct/Questions \\
\hline & Farm and crop development \\
\hline Q1 & Agricultural extension services of Edo ADP have impacted food crop development in my community \\
\hline Q2 & Agricultural extension services of Edo ADP have impacted cash crop development in my community \\
\hline Q3 & Agricultural extension services of Edo ADP have impacted farm development in my community \\
\hline & Agricultural extension services of Edo ADP have enhanced the provision of water my community \\
\hline Q4 & Agricultural extension services of Edo ADP have enhanced the provision of access roads my community & Infrastructural development \\
\hline Q5 & Agricultural extension services of Edo ADP have enhanced the provision of basic amenities my community & \\
\hline Q6 & Reduction of unemployment & \\
\hline Q7 & Agricultural extension services of Edo ADP have increased job opportunities in my community \\
\hline Q8 & Agricultural extension services of Edo ADP have reduced the level of unemployment my community \\
\hline
\end{tabular}

attempt to increase the sample size used in this study in order to enhance the reliability of the findings consistent with the central limit theory.

Note: Strongly Agree = 5; Agree = 4; No View = 3; Disagree = 2; and Strongly Disagree =1.

a. Age category in years: Under 30 [ ] $31-40$ [ ] 41 - 50 [ ] 51 and above [].

b. Sex: Male [] Female [].

c. Marital status: Married [ ] Single [ ] Divorced [ ] Widowed [].

d. Local Government Area: Oredo [ ] Egor [ ] Ikpoba Okha [].

\section{References}

1. Inegbedion HE (2012) Oil price hike and the Nigerian economy: The Impact of Oil Price Hike on the prices of Products from Non-Oil Sectors in Nigeria. Lap Lambert Academic Publishing. GmbH \& Co. KG, Saarbrucken, Germany.

2. Independent Evaluation Group (2009) Agricultural developments in Nigeria.

3. Ammani AA, Auta SJ, Aliyu JA (2010) Challenges' to sustainability: Applying the problem tree analysis methodology to the ADP system in Nigeria. Journal of Agricultural Extension 14(2): 36-46.

4. Adamu MU, Mohammed WA (2009) The effect of agricultural development project (ADP) on the rural farmers in Adamawa state, Nigeria. Asian Journal of Agriculture and Rural Development 2(3): 405-410.

5. Enwelu IA, Enwereuzor SO, Asadu AA, Walleji HO, Nguoke BC (2017) Access and Use of Information Communication Technologies in Anambra State ADP, Nigeria. Journal of Agricultural Extension 21(2): 152-161.

6. Naswem AA, Ejembi SA (2017) Reviving agricultural extension for effective transition from subsistence to commercial agriculture in Nigeria. Journal of Rural Social Sciences 32(1): 3-20.

7. Umeh OJ, Ekumankama 00, Nwachukwu I, Ekwe KC (2015) Comparative performance evaluation of the Agricultural development programmes of Abia and Enugu states, Nigeria. Journal of Agricultural Extension 19(2): 108-114.

8. Omonijo DO, Toluwase SOW, Oludayo OA, Uche OOC (2014) Impacts of Agricultural Development Programme (ADP) on Rural Dwellers in Nigeria: A Study of Isan-Ekiti. International Research Journal of Finance and Economics 128: 41-55.

9. Nchuchuwe FF, Adejuwon KD (2012) The Challenges of agriculture and rural development in Africa: The case of Nigeria. International Journal of Academic Research in Progressive Education and Development 1(3): 47-61.

10. Ugwu DS (2007) Contributions of agricultural development programmes (ADPs) to rural livelihood and food security in Nigeria. Agricultural Journal 2(4): 503-510.

11. Olujenyo FO (2006) Impact of Agricultural Development Programme (ADP) on the Quality of Social Existence of Rural Dwellers in Developing Economies: The Ondo State (Nigeria) Agricultural Development Programme Experience. International Journal of Rural Management 2(20): 213-226.

12. Titilayo ST (2001) Environment and sustainable agricultural development in Nigeria.

13. Nwachukwu IN, Eze CI (2007) Impact of selected rural development programmes on poverty alleviation in Ikuano Local Government Area, Abia state Nigeria. African Journal of Food, Agriculture, Nutrition and Development, Kenya.

14. Agbadudu AB (2007) Statistics for business and the social sciences, Benin: Uri publishing company limited, Nigeria.

15. Agbonifoh BA, Yomere GO (2002) Research methodology in the social sciences and Education, Centrepiece Consultancy limited, Benin City, Nigeria.

16. Chiegwe 0 (2000) Urban-biased development and rural peripheralisation in post-colonial Nigeria: some theoretical consideration, Benin Journal of Social Sciences, Vols. 8\&9, Benin City, Nigeria. 
17. Cotonou Agreement (2008) Economic development.

18. Edokpa DA, Okafor FC (2009) Rural development: A link to food security in Nigeria. Benin Journal of Social Sciences, Benin City, Nigeria.

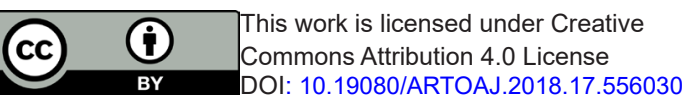

19. Seers D (1979) The Meaning of development. International Journal of Development Review 11(4): 32-41.

20. Statistical Package for Social Sciences (1999) Independent Samples Test, SPSS inc, New York, USA.

\begin{tabular}{l} 
Your next submission with Juniper Publishers \\
will reach you the below assets \\
- Quality Editorial service \\
- Swift Peer Review \\
- Reprints availability \\
- E-prints Service \\
- Manuscript Podcast for convenient understanding \\
- Global attainment for your research \\
- Manuscript accessibility in different formats \\
( Pdf, E-pub, Full Text, Audio) \\
- Unceasing customer service \\
Track the below URL for one-step submission \\
https://juniperpublishers.com/online-submission.php \\
\hline
\end{tabular}

